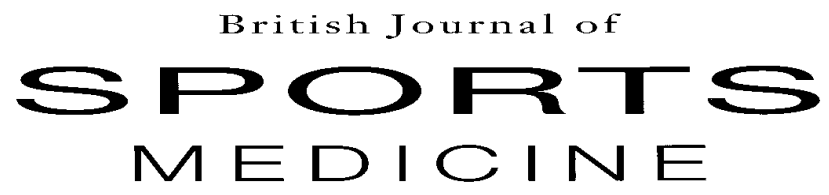

\title{
Editorials
}

\section{Warm down}

A parting gift. Some memorable papers that made us smile. Astrology is not our strongest suit and, as scientists, our first response was that perhaps the postman had got it wrong (page 465). Strange, unusual, intuitively, and intellectually challenging. But fascinating. In the scientific world of sport, dominated by physiologists, biochemists, pharmacists, and even geneticists, the idea that performance could be related in some way to the path of the moon and the stars sounds daft at first. Can you imagine the implications? Pregnancies planned to coincide with astrological events. Multi million pound transfer deals determined by heavenly bodies. Never mind your goal scoring record, tell us your star sign.

Fishing injuries. It's sport, it's injury-yes, it's the right journal. Looking for a reviewer, no one came to mind immediately. Nothing in the medical literature was even close. The paper that nearly got away (page 459). We finally found two reviewers; a kilted colleague on a Scottish island, and a Gaelic speaking part time GP in the west of Ireland. So you don't think it is relevant to our journal? Wait until you try removing a fishhook.
You adjourn to a local hostelry after a day of fishing. Revived by a day on the lake, the power of nature and the rise of the trout and, strengthened by strong liquor, you challenge your barstool neighbour to a bout of arm wrestling. Sporting injuries are everywhere (page 461); you have been warned.

Non-sporting folk often wonder what makes us tick. They say you never see a happy jogger; that sport is all brawn and no brain. They see no sense in chasing a little white ball across a field or a little black ball around an empty room. We know better. Quite an artistic bunch, really. Closet poets. For, in the safe company of friends we wax eloquent about the magical quality of a morning run on a crisp winter dawn, the effortless flow of a racing eight on a mirrored lake, leather on willow, the beautiful game. And so we invited our resident bard to review the contribution of poetry to sport; to see if poets can capture that special quality that makes sport so addictive (page 472). Iambic pentameter and sporting eloquence. Slán agus beannacht.

\section{BJSM Online at a screen near you: www.bjsportsmed.com}

This issue of British fournal of Sports Medicine sees the launch of BJSM Online-a full text, sophisticated web site. The internet has long been an invaluable resource for science and medicine, and many publishers have recognised its potential to disseminate important research and to increase awareness of their journals internationally. A few years ago there were fewer than 100 journals online, now there are thousands with an exponential rise in the number expected to occur over the next few years. In fact, an article in Nature predicted that a journal without a full text web site is heading for extinction. ${ }^{1}$ BFSM has had an internet presence for some time but its web site was rather basic (just tables of contents and general information). The new site has the same address-www.bjsportmed.com-but it has moved to California.

$B F S M$ has joined its illustrious cousin the BMF, and many other important medical journals, at HighWire Press, a division of Stanford University's Green Library. HighWire's mission is to "foster research and instruction by providing a more direct link between the writers and readers of scholarly materials". ${ }^{2}$ As visitors to the BMFs web site (www.bmj.com) will know, online journals can have many features that add value to the important research contained within the print version. One of the many benefits of being part of the

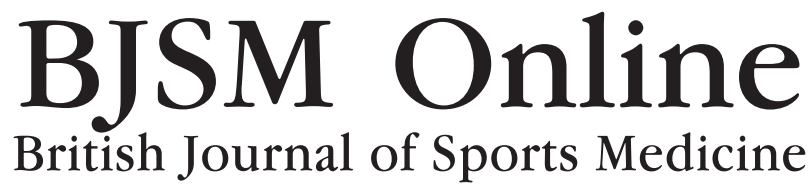

HighWire stable is that all publishers agree to share "toll free links" - this means that references to any of the more than 200 journals hosted by HighWire link directly to the full text of that article without any subscription charges. In addition, the BMJ Publishing Group aims to join the CrossRef initiative whereby references will link directly to articles in participating journals regardless of where they are hosted (access to full text will be determined by the individual publisher). References to non-HighWire journals already link directly to the Medline listing where available and we are working towards similar links to ISI's Current Contents. These hyperlinks are just one of the ways in which we hope to exploit the mass of information available online.

Each new issue of BFSM will be available in full (including figures and tables) with additional "web extra" material. Full text articles have downloadable "printer friendly" pdf files so you don't have to read them on screen. There is a fully searchable archive going back to March 
1998, as well as abstracts and tables of contents from much earlier issues. It is possible to search across all or a selected set of the more than 200 HighWire journals which cover many aspects of clinical medicine and basic science. Email (a) 1erts will automatically alert you when a new issue is available; these will soon be customisable to your particular area of interest. The "Collections" feature allows you to search quickly for material in subspecialty areas and this feature links directly with the $B M F$ and other specialist journals in the BMJ Publishing Group stable.

BFSM Online will be more than just an electronic mirror of the print journal. The benefits of cross journals searching and linking are immense. In addition you can have your say on anything published in the journal by using the "eLetters" feature. Your comments about an article can be submitted online and posted within a few days (subject to editorial screening). Additional material including tables, illustrations, and references that cannot find space in the print journal are easily accommodated online. Multimedia features can be added, including video and audio clips. The future may well see: immediate online publication of important research; important results from major conferences highlighted within days; interactive educational material; and virtual journals customised by the reader. In addition, we plan to introduce online submission and peer review of papers within the next year or so.

Each issue of BfSM will be put online at the same time as the print version is distributed; therefore, readers outside the UK will not have to wait for days or weeks to enjoy the journal. Access to BFSM Online will be free until March 2001 ; it will then be available at no charge to personal print subscribers (including members of the British Association of Sport and Exercise Medicine). Online only subscriptions will be available to personal subscribers, and institutions can purchase a site licence allowing access to all qualifying members from both within the institution and off site (details available on the web site). Non-subscribers will be able to purchase individual articles or short term access to the whole site.

The rapid advances in information technology and the immense penetration of the internet around the world means that important medical research can reach more people more quickly. BFSM is pleased to embrace these advances so that rather than "face extinction" the journal evolves to provide relevant material to the international sports medicine community where it needs it and when it needs it. We aim to fulfil the needs of authors and readers so we welcome your comments on these developments both through the web site and more traditional methods.

Editor

D MACAULEY

\section{Managing Editor}

JANET O'FLAHERTY

1 Butler D. The writing is on the web for science journals in print. Nature 1999;397:195-200

2 About HighWire Press. highwire.stanford.edu/about.shtml

\section{Yesterday's heroes}

Yesterday's heroes living on their memories. A great past to look forward to. It comes to us all. The day you realise that your past has arrived and that, inevitably, your future is downhill. When life is sweet, races run fast, there is no tomorrow. Success leads to success, every training session brings new challenges and every season new opportunities. Kick off the bend, the roar of the crowd. But that someday always comes. When athletes begin to choose their races, players worry about the coming season, and boxers believe in that last great fight. Maybe an injury, perhaps a missed tackle, a training session that hurts just a little too much, or a race that slips out of reach. The doubts begin. Anno Domini offers relentless opposition.

Sport creates its own heroes. We worship our sporting idols, the Olympic champions, the international footballers, and the leading players in our chosen sport. We cherish them at their peak, but soon forget. A half time hotdog. Professional athletes may be well paid, but they are in the minority. The lucky ones have an income and sponsorship that gives them an independent livelihood. Others dedicate their lives to minority amateur sports for a brief moment of televised glory every four years. And then it ends.

We know what it takes to make champions: the dedication, the determination, and the sacrifices. National figures become international celebrities. Anonymity becomes a household name. Even those who play on the village team are feted locally. For a while. Having dedicated their young life to sport, given up educational opportunities and potential employment, they are left to fend for themselves when their sporting career is over. No skills, no qualifications, just a handful of medals and a drawer full of tracksuits. But no job.

The life change is enormous. Yesterday a hero, today discarded. Perhaps it is time to ask if those who dedicate their lives to sport know the price they pay. We know that some may suffer injury that haunts them for the rest of their lives. But, even those with a successful career may be psychologically scarred by the inevitable slide from hero to zero. Public opinion, sporting administration (and that includes you!) encourage young people to aim for sporting excellence, and we are not afraid to show them what is needed. But, the opportunity costs are huge. We read in the newspapers that young people are not interested in committing themselves to top level sport. If they know the price, it is little wonder.

Perhaps we in sport and exercise medicine have a responsibility. If we are truly on the side of the athlete, our care should be focused not just on the moment and the next event but in the future. Our duty of care may extend to holistic care beyond their sporting career. We may have an administrative position on a national body, in an international committee, within a sporting institute and, with it, the opportunity to influence the long term of athletes. Athletes need to know to prepare for life after sport, to achieve the educational qualifications to enable them to make their way in the world after sport. They must be psychologically prepared for the ego crash on the way downhill. We have a duty to prepare the way, in detraining athletes, in cushioning their fall from stardom, and rehabilitating them into the real after life in the sporting incubator. A market economy leaves them on their own, the sporting machine spits them out after use, and when the new generation moves in yesterday's heroes get in the way. There is no one else to speak up for these former athletes. Those who cope survive, those who cannot cope are still our patients. As doctors, we are our patients' advocate.

Editor, British fournal of Sports Medicine 